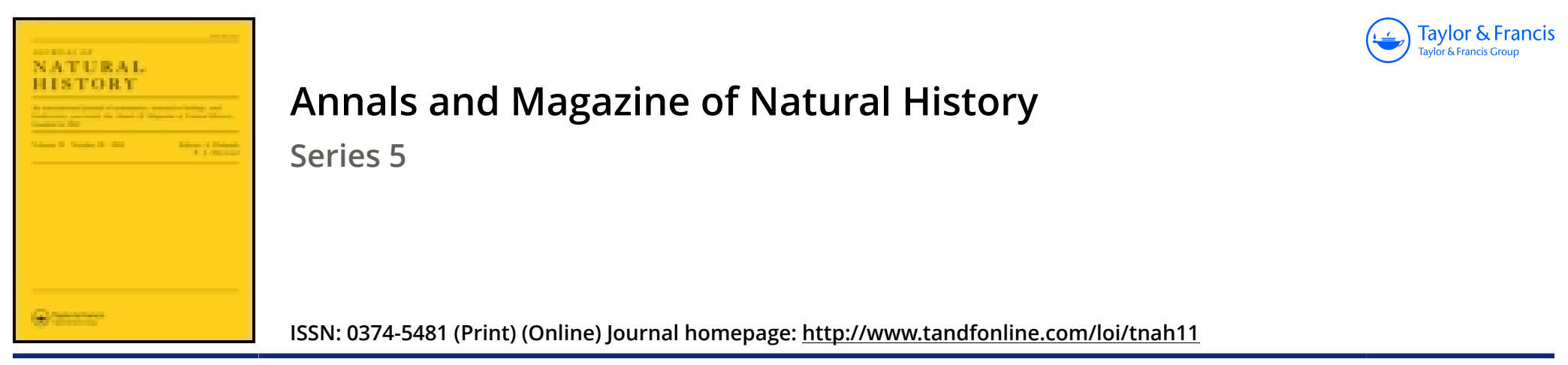

\title{
XVII.-A note on the characters of the genus Crossaster, with the description of a new species
}

\section{F. Jeffrey Bell M.A.}

To cite this article: F. Jeffrey Bell M.A. (1881) XVII.-A note on the characters of the genus Crossaster, with the description of a new species, Annals and Magazine of Natural History, 8:44, 140-142, DOI: $10.1080 / 00222938109487428$

To link to this article: http://dx.doi.org/10.1080/00222938109487428

\section{Published online: 09 Oct 2009.}

\section{Submit your article to this journal $\square$}

Џ Article views: 3 
XVII.-A Note on the Characters of the Genus Crossaster, with the Description of a new Species. By F. JefFreY BELI, M.A.

I HAD hoped to accompany the description of the new species of Solaster which forms the body of this note by an investigation into the distinctive characters of the apparently three generic types which have been associated together under Forbes's name Solaster; but I find from a late number of the 'Nyt Magazin' that the two eminent Norwegian naturalists, Messrs. Danielssen and Koren, are about to publish some observations on this point. I shall therefore deal very briefly with one or two characters of these forms, and shall exhibit the respect which I feel for the workers just named by deferring to their right of speech.

The time has certainly come when greater care must be taken in referring species to the genus Solaster. Even if we allow that Müller and Troschel were justified in placing $S$. endeca and $S$. papposus in the same genus, there can be no doubt that Prof. Verrill has done good service to the correct estimation of generic differences by establishing the genus Lophaster * for the S. furcifer of Düben and Koren; while, lastly, there can be no doubt that the S. tumidus of Stuxbergf is more correctly placed with the genus Asterina, as is now proposed by Messrs. Danielssen and Koren in the essay to which $I$ have just referred.

Although Lütken, Sladen, and Agassiz have all entered into some discussion of the question, and have all been inclined to separate $S$. endeca and $S$. papposus into different genera, the absolute characters which distinguish them seem never to have been distinctly formulated. The last-named writer expresses himself very strongly on the unnatural alliance; for he says $\ddagger$, "From an examination of the hard parts it is evident that Solaster papposus and Solaster endeca should not be included in the same genus, having really nothing in common except the great number of arms."

This remarkable statement has been searchingly dealt with by Dr. Viguier $\$$, who undoubtedly has the better position in the controversy on the facts called in evidence; but that excellent investigator seems to me to have not fully weighed

* Am. Journ. Sc. (3) xvi. p. 216.

† OEfv. K. Vet. Akad. Förh. Stockholm, 1878 (1879), no. 3, p. 31.

† Mem. Mus. Comp. Zool. v. no. 1 (1877), p. 98.

$\S$ Arch. de Zool. Exp. vii. p. 139. 
all the facts which can be made out with regard to these two forms, which he retains in one genus.

I will here only direct attention to the gradation in characters, which, till the publication of Messrs. Danielssen and Koren's studies, induces me to regard Solaster, Crossaster, and Lophaster as distinct genera.

When we examine the actinal surface of a ray of $S$. endeca we observe that, externally to the transverse set of spines which runs near the ambulacral groove, there is a series of special plates bearing a comb of spines: though in a sense marginal, these plates are quite confined to the actinal surface; from the dorsal view one would not have the least suspicion of their existence. It is not so with C. papposus ; for in it the modified marginal plates are set on the upper part of the side of the ray, and form a regular series of dorsomarginal plates. Coming lastly to Lophaster, we find that the "differentiated marginal plates" of which Prof. Verrill speaks exhibit a striking advance on what has been seen in Solaster or in Crossaster: there are now two sets, one dorsomarginal and one ventro-marginal.

A gradational series so well marked does, I submit, afford very considerable support to the view that the three forms in question belong to distinct though allied genera.

\section{Crossaster neptuni, n. sp.}

Arms ten : $\mathrm{R}=50, r=25$.

A species of the character of $C$. papposus, but distinguished from it by the absence of the glassy spines on the paxillæ and by the smaller number, larger size, and greater regularity of the paxilla themselves.

The spines in the single adambulacral row which fringes the groove are generally placed by threes on each plate; near the actinostome, however, four spines may be found on a plate; the spines are short and stout. About five or six similarly rather stout spines are found in each set of the transverse rows; they are not spread out in fan-shape, as they are in S. papposus. The interbrachial space is small, and has scattered over it pairs or triplets of short spines, just sufficiently numerous to relieve it from an appearance of bareness. The outer free edge of this space (interbrachial angle) is occupied by a collection of small spines arranged in form of a double tooth-comb; there are about twelve of these special bundles of spines; and they, as they pass outwards, rapidly mount to the dorsal edge of the arm, to which they give a very characteristic appearance. The double tooth-comb arrangement soon yields to a more irregular disposition, and 
the spinelets form rather a fasciculus or bundle set on a rounded base; there are no glassy spines in connexion with these bundles, which, as they approach the tip of the arm, gradually diminish in size.

Along the middle line of each ray, and even as far as the centre of the disk, it is quite easy to detect the regular arrangement of the chief paxillæ. A bout twelve of these can be made out in each row; and they add much to the distinctness of the several rays.

In addition to this row of specially large and conspicuous paxillæ, two sets at least of smaller ones are to be made out on either side of each of them. Similarly the somewhat wide spaces between each of the more important paxillæ are occupied by smaller paxillæ. The rest of the abactinal surface, whether on the free portion of the rays or on the disk itself, is occupied by single spines, by spines a few together, or by papulæ; but none of the spines are either long or sharp.

The single madreporic plate, which is situated a little way from the centre of the disk, is of a moderate size and sufficiently easy of detection.

Ecuador. Coll. B.M.

The single specimen from which this description has been drawn up has been at least twenty-five years in spirit; it is of a creamy-yellow colour. It was collected by S. O. Goodridge, Esq., R.N., and formed part of the Haslar collection.

XVIII.-Notes on Longicorn Coleoptera.-Revision of the Arénicides and Amphionychides of Tropical America. By H. W. Bates, F.R.S., F.L.S.

WiтH the exception of three genera-Oberea, Tetraopes (northern forms, spreading across the Mexican frontier partly into Central America), and Phoea-all the true Saperdinæ of Tropical America belong to Lacordaire's "groupes" Amphionychides and Frénicides. These are distinguished from temperate and Old-World forms of Saperda not by any constant peculiarity of structure, but a combination of characters and the occurrence in many of the genera of special features not existing in any other groups of the subfamily. In these remarks it will be understood that I recombine the original Saperdoe and their allies with the Phytcecice, placed in Lacordaire's system so wide apart, and form with them a subfamily Saperdinæ, equivalent to the true Lamiinæ, Niphoninæ, Acanthoderinæ, \&c., and that I exclude the groups Calliides, Gryl- 